\title{
Desarrollo de marcadores moleculares para la identificación de especies de Eucalyptus
}

\section{Development of molecular markers for the Eucalyptus species identification}

\author{
Hernando J. Rivera-Jiménez ${ }^{1 *}$, Bruno C. Rossini², Vanusa do S. Leite ${ }^{2}$, Paulo HM. Da Silva ${ }^{3}$ \\ and Celso L. Marino ${ }^{4}$
}

Recibido para publicación: Diciembre 14 de 2016 - Aceptado para publicación: Mayo 18 de 2017

\begin{abstract}
RESUMEN
Uno de los principales problemas que enfrentan los programas de mejoramiento genético en eucaliptos es la dificultad para identificar las especies e híbridos. El objetivo de este estudio fue encontrar marcadores moleculares asociados a cinco especies de Eucalyptus (E. saligna, E. tereticornis, E. urophylla, E. grandis and E. brassiana), mediante marcadores AFLP (Amplified Fragment Length Polymorphism) y BSA (Bulk Segregant Analysis), para su uso en programas de mejoramiento genético en Brasil. En 33 combinaciones de cebadores, se obtuvo un total de 868 fragmentos polimórficos, que representan un $91,65 \%$ del polimorfismo. Las mejores combinaciones que muestran potenciales marcadores para la identificación de especies, fueron encontradas en los cebadores M+GGT/E+ACC, que estuvo un $70 \%$ de los individuos asociados a la especie E. urophylla. Sin embargo, la combinación de cebadores compuesta de M+GGA/E+ACC identificó el $60 \%$ de individuos en la especie E. saligna; la combinación de los cebadores M+GTC/E +AAC, confirmó dos marcas, una en $60 \%$ y la otra en $50 \%$ para la identificación de individuos de la especie E. grandis. El tratamiento compuesto por los cebadores M+GGC/E+AAA, confirmó un 30\% de los individuos perteneciente a la especie $E$. brassiana, siendo igual para la combinación de cebadores M+GGC/E+ACC, identificando el $30 \%$ de los individuos de la especie $E$. tereticornis. El análisis AFLP en asocio a BSA proporcionan una herramienta rápida para la identificación de cultivares en Eucalyptus, a la vez de que puede ser usados en los programas de mejoramiento genético forestal.
\end{abstract}

Palabras clave: AFLP- BSA, Eucalyptus, identificación de especies.

\begin{abstract}
One of the main problems faced in several eucalypt breeding programs is the difficulty to identify the species and hybrids. This study aimed to find molecular markers associated with five species of Eucalyptus (E. saligna, E. tereticornis, E. urophylla, E. grandis and E. brassiana), by AFLP (Amplified Fragment Length Polymorphism) markers and BSA (Bulk Segregant Analysis), for their use in breeding programs in Brazil. In 33 primer combinations, a total of 868 polymorphic fragments was obtained, which represent a $91.65 \%$ of polymorphism. The best combinations that show potential markers for species identification were the primers $M+$ GGT / E + ACC, which was linked to $70 \%$ of $E$. urophylla individuals. However, primer combination composed of M+GGA/ $\mathrm{E}+\mathrm{ACC}$ identified $60 \%$ of individuals in the $\mathrm{E}$. saligna species; combination by the primers $M+G T C / E+A A C$, confirmed two marks, one in $60 \%$ and the other in $50 \%$ of $E$. grandis individuals in the identification test. The treatment composed by the primers $\mathrm{M}+\mathrm{GGC} / \mathrm{E}+\mathrm{AAA}$, was confirmed in only $30 \%$ of $E$. brassiana individuals, being the same for the combination M+GGC/E+ACC primers, identifying $30 \%$ of $E$. tereticornis individuals. The AFLP analysis and BSA provide a quick tool for the identification of cultivars in Eucalyptus and can also be used to assist forest breeding programs.
\end{abstract}

Key words: AFLP, BSA, Eucalyptus, species identification

\footnotetext{
$1^{*}$ PhD. Biological Sciences-Genetics. Universidade Estadual Paulista. Departamento de Genética, Instituto de Biociências, Distrito de Rubião Junior, Caixa postal 510 - CEP: 18618-970 -, Botucatu - SP, Brasil. Corresponding author: E-mail: hriveraj@gmail.com

${ }^{2}$ PhD. Biological Sciences-Genetics. Universidade Estadual Paulista. Departamento de Genética, Instituto de Biociências, Distrito de Rubião Junior, Caixa postal 510 - CEP: 18618-970 -, Botucatu - SP, Brasil. Corresponding author: E-mail: hriveraj@gmail.com

3 PhD. Forest resources. Instituto de Pesquisas e Estudos Florestais, Av. Pádua Dias 11, C. P. 530, CEP 13400-970, Piracicaba, SP, Brasil.

${ }^{4}$ PhD. Biological Sciences-Genetics. Universidade Estadual Paulista. Instituto de Biotecnologia / IBB- UNESP/, Botucatu, SP, Brasil.
} 


\section{INTRODUCCION}

The area of trees planted for industrial purposes in Brazil totaled 7.74 million hectares in 2014, an increase of $1.8 \%$ over 2013. This total corresponds to only $0.9 \%$ of Brazilian territory. The overall success of the Brazilian forestry industry is a result of the high productivity of trees planted in the country. For example, in Brazil, the forest area required for the production of 1.5 million tons of pulp per year is 140 thousand hectares (IBA 2015). The Brazilian genetic improvement program has the general objective of making available to the different Brazilian regions with sufficient genetic variability in such a way that it obtains plants more adapted to the different environments to meet the demands of wood for multiple uses (Santos 2011). Eucalyptus are planted on a large scale due to their high productivity obtained by breeding program that explored the adaptability of genus species to different environmental conditions (Gonçalves et al. 2013). Know the species that are being worked in the breeding program is important for the strategic planning, especially to identify interspecific hybrids and germplasm conservation (Poltri et al. 2003; Ballesta et al. 2015). Overall, a good breeding program selects the best individuals in intrafamily level, increasing the plantations operating performance and industrial products quality (Grattapaglia and Kirst, 2008). Brazilian forest breeding programs aim to provide for all Brazilian regions enough genetic variability in order to obtain plants adapted to different environments to attend the demand for wood (Forrester and Smith 2012). However, one of the problems is the difficulty to identify the species, especially in hybrid combinations (Grattapaglia et al. 2004). In this context, the incorporation of molecular biology techniques in plant breeding programs is allowing the optimization of time and the conduction of these programs, being the hybrid plants, selected for planting most of the time (Pongitory et al. 2004; Soares et al. 2010). In Eucalyptus sp., the hybridization strategy can significantly increase production and adaptability in the resulting progeny, while the hybrid plants are commonly selected to be part of the commercial plantation, selection based on phenotypic superiority and genetic stability (Potts and Dungey 2004). According to Silva et al. (2016), it is possible that the number of commercially unused hybrid species increases, this is due to the new biotic and abiotic stresses that can occur with climate change. This increase in the number of species involved will make it even more difficult to identify, if there is no reliable and practical tool, it will be difficult to use the hybridization intensively, whose use has been expanding for years (Denison and Kietzka 1993). A tool to assist the breeding programs are the molecular markers. Bulked segregant analysis (BSA) is a method introduced by Michelmore et al. (1991), which has been used to identify molecular markers linked to a monogenic, dominant or recessive trait. The technique consists in comparing two sets of DNA samples from a segregating population, where each bulk is composed of individuals from the same species that have the same trait or gene of interest (Blanco and Valverde 2005; Fuchs et al. 2011). The AFLP (Amplified Fragment Length Polymorphism) markers are high efficient for detecting polymorphism of genomic restriction fragments by PCR amplification (Polymerase Chain Reaction) (Vos et al. 1995). These markers are applied in genetic diversity studies in germplasm banks (Rivera-Jiménez et al. 2011) and allow to obtain a large number of tags randomly distributed in the genome (Vos et al. 1995). The use of molecular markers in eucalypt breeding programs already occurs for many years, the markers are used with good results for genetic diversity studies pedigree reconstruction, crossing rate, endogamy study, population genetic structure, genetic flow study, contamination of natural areas or seed orchards (Brondani et al. 1998; Barbour et al. 2005; Jones et al. 2005; Jones et al. 2008; Payn et al, 2008; Silva et al. 2014; Mora et al. 2016; Randal et al. 2016; Silva et al. 2017). 
Also provides early identification of the individuals used and maximizes genetic gains (Silva et al. 2015). in the same way is used in industrial timber planning, by identifying genetic hybrids and early identification of species of eucalyptus (Ishii 2009). This study aimed to identify molecular markers associated with five species of Eucalyptus sp., through AFLP molecular markers and bulked segregant analysis (BSA).

\section{MATERIAL AND METHODS}

A total of 10 individuals from five Eucalyptus species was provided by Suzano Paper and Cellulose Company (Suzano Papel e Celulose $\mathrm{SA})$. The three main species (E. grandis, $E$. saligna and E. urophylla) of Brazilian forestry were among the nine most cultivated Eucalyptus species in the world (Harwood 2011). Also evaluated were two species of importance for plantations with abiotic stress and that are used to obtain hybrids in commercial crops. table 1. Genomic DNA was extracted according to the CTAB protocol described by Doyle and Doyle (1990), with some modifications as follow: $5 \% \mathrm{CTAB}$, removing the proteinase $\mathrm{K}$ extraction buffer; CIA step (chloroform: isoamyl alcohol 24:1), was carried out only once; and finally, it was removed the cleaning step with $\mathrm{NaCl}$ to extract the DNA from fresh leaves. For each sample, approximately $50 \mathrm{mg}$ of fresh leaf tissues was macerated without main vein. Quantification was performed in spectrophotometer Nano Drop®- ND1000. The DNA used in the amplification reactions was absent of impurities and phenolic compounds,

Table 1. Proceedings of Eucalyptus species used for identification with AFLP-BSA markers.

\begin{tabular}{ll}
\hline \multicolumn{1}{c}{ Especies } & \multicolumn{1}{c}{ Origin } \\
\hline Eucalyptus brassiana & Embrapa - CSIRO 10972 (North Moreton, \\
& QLD, Austrália) \\
Eucalyptus saligna & Coffs Harbour (Austrália) \\
Eucalyptus grandis & Coffs Harbour (Austrália) \\
Eucalyptus urophylla & IPEF - Timor \\
Eucalyptus tereticornis & Embrapa - CSIRO 10975-8140 (Cooktown e \\
& Laura, QLD, Austrália) \\
\hline
\end{tabular}

diluted to a concentration of $50 \mathrm{ng} / \mu \mathrm{l}$ in autoclaved ultra-pure water.

Five species of Eucalyptus identifcated as $E$. saligna, E. tereticornis, E. urophylla, E. grandis and $E$. brassiana were analizated, building a bulk for each specie composed of 10 individuals, in a DNA concentration of $10 \mathrm{ng} / \mu \mathrm{L}$ per individual and the final concentration of each bulk were $100 \mathrm{ng} / \mu \mathrm{L}$. The DNA bulks were screened for polymorphic markers using AFLP markers in order to identify polymorphisms associated with each specie. AFLP protocol was adapted from Vos et al. (1995). Genomic DNA was digested with a combination of two enzymes, EcoRI + Msel. 700 ng of DNA were digested with $5 \mathrm{U}$ per enzyme, 5 uL of One Phor All buffer (OPA, Amersham), $0.5 \mathrm{uL}$ of BSA (10 ug / uL) in a final volume $50 \mathrm{uL}$. The reaction was incubated at $37^{\circ} \mathrm{C}$ for 16 hours. Amplified products were visualized after electrophoresis in $0.8 \%$ agarose gel in $1 \times$ TBE (Tris-Borate-EDTA) stained with ethidium bromide and visualized under UV light transilluminator. The EcoRI adapter was diluted to $5 \mathrm{pM}$ solution containing $0.5 \times$ One Phor All buffer 10x (OPA). The Msel adapter was diluted to $50 \mathrm{pM}$ solution $0.5 \times$ One Phor All buffer 10x (OPA). The hybridization of adapters was performed in a thermocycler model PTC-100 (MJ Research $(B)$ in a reaction consisted of 10 $\min 65^{\circ} \mathrm{C}, 10 \mathrm{~min}$ at $37^{\circ} \mathrm{C}$ and $10 \mathrm{~min}$ at $25^{\circ} \mathrm{C}$. The adapters were ligated to the DNA fragments in a reaction containing $1 \mathrm{uL}$ of the enzyme T4 DNA ligase buffer (10x), 1 uL of each adapter (5 or $50 \mathrm{pM}$ ), 3U T4 DNA ligase (Invitrogen, Carlsbad CA, USA), 6.67 uL of ultrapure water and $45 \mathrm{uL}$ digested DNA solution. Ligation was performed at $17{ }^{\circ} \mathrm{C}$ for 17 hours. There were four combinations of primers in the preamplification reactions (Ea / Mg and Ea / Mc), primers with complementary sequences to each of the adapters plus one selective nucleotide at the 3 'end (Table 2). The reactions were composed with $1 \mathrm{uL}$ of each primer (25 ng /

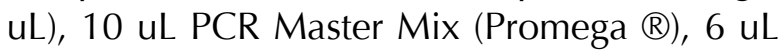
Nuclease-Free Water and $2 \mathrm{uL}$ digested and 
Table 2. Sequence of the adapters and primers used in the binding reactions, pre-amplification and amplification of the AFLP technique.

\begin{tabular}{|c|c|}
\hline Adaptor or primer & Oligonucleotide \\
\hline EcoRI adaptors & 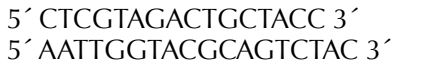 \\
\hline $\begin{array}{l}\text { Pre-selective amplification } \\
\text { primer } N: T \text { ou } A\end{array}$ & 5' GACTGCGTACCAATTCN 3' \\
\hline $\begin{array}{l}\text { Selective amplification } \\
\text { primer NNN: AAA, } \\
\text { Msel adaptors }\end{array}$ & $\begin{array}{l}5^{\prime} \text { GACTGCGTACCAATTCNNN 3' } \\
5^{\prime} \text { GACGATGAGTCCTGAG 3' } \\
5^{\prime} \text { 'TACTCAGGAACTCAT 3' }\end{array}$ \\
\hline $\begin{array}{l}\text { Pre-selective amplification } \\
\text { primer N:T ou A }\end{array}$ & 5' GATGAGTCCTGAGTAAN 3' \\
\hline $\begin{array}{l}\text { Selective amplification } \\
\text { primer NNN: } A A A,\end{array}$ & 5' GATGAGTCCTGAGTAANNN 3' \\
\hline
\end{tabular}

ligated DNA in a final amount of $20 \mathrm{uL}$. The program for preamplification was: $94{ }^{\circ} \mathrm{C}$ for 2 min, 26 cycles of $94{ }^{\circ} \mathrm{C}$ for 1 minute, $56{ }^{\circ} \mathrm{C}$ for 1 minute, $72{ }^{\circ} \mathrm{C}$ for 1 minute and a final extension at $72^{\circ} \mathrm{C}$ for 5 minutes. In the product of this reaction was added $80 \mathrm{uL}$ of ultrapure water. A A total of 33 primers combinations for selective amplification were tested (Table
$3)$. In these reactions were used primers with sequences containing more three selective nucleotides at the 3 'end (Table 2), composed of $1 \mathrm{uL}$ of each primer (25 ng / uL), $10 \mathrm{uL}$ PCR Master Mix (Promega (®), 6 uL Nuclease-Free Water and 2 uL of pre-diluted reaction, in a final volume of $20 \mathrm{uL}$. The conditions for selective amplification was: $94{ }^{\circ} \mathrm{C}$ for 2 min, 12 cycles of $94{ }^{\circ} \mathrm{C}$ for 30 seconds, $65{ }^{\circ} \mathrm{C}$ for 30 seconds and $72{ }^{\circ} \mathrm{C}$ for $1 \mathrm{~min}, 23$ cycles of $94{ }^{\circ} \mathrm{C}$ for 30 seconds, $56{ }^{\circ} \mathrm{C}$ for 30 seconds and $72{ }^{\circ} \mathrm{C}$ for 1 min, with final extension at $72{ }^{\circ} \mathrm{C}$ for 2 minutes. After that, were added $8 \mathrm{uL}$ of loading buffer. The samples were denatured for 5 minutes at $94{ }^{\circ} \mathrm{C}$ and visualized after electrophoresis in a $6 \%$ polyacrylamide gel, $0.5 \mathrm{~mm}$ thick with the System "Sequi-Gen GT" (BioRad $($ )), stained with silver nitrate according to the protocol proposed by Creste et al. (2001). In cases of polymorphic fragments, their size was estimated by comparison with standard molecular weight of $100 \mathrm{bp}$ (Promega $\AA$ ).

Table 3. Combinations of primers used to obtain Eucalyptus AFLP markers.

\begin{tabular}{ccccccccc}
\hline \multirow{2}{*}{ Treatment } & \multicolumn{2}{c}{ Primer combinatons } & Treatment & \multicolumn{2}{c}{ Primer combinatons } & Treatment & \multicolumn{2}{c}{ Primer combinatons } \\
\cline { 2 - 8 } & MSel & Eco $R I$ & & MSel & ECo $R I$ & & MSel & Eco $R I$ \\
\hline 1 & GTG & AGA & 12 & CAA & AAC & 23 & GAA & AAA \\
2 & GTG & AGC & 13 & CAA & AAA & 24 & GAA & AAC \\
3 & GTG & AGG & 14 & CAT & AAA & 25 & GAA & ACC \\
4 & GTG & ACA & 15 & CAT & AAC & 26 & GGC & AAA \\
5 & GTT & AGC & 16 & CAT & ACC & 27 & GGC & AAC \\
6 & CAG & AAC & 17 & CCT & AAA & 28 & GGC & ACC \\
7 & CAG & AAA & 18 & CCT & AAC & 29 & GGT & AAA \\
8 & CAG & ACC & 19 & CCT & ACC & 30 & GGT & ACC \\
9 & CAC & AAC & 20 & GTC & AAA & 31 & GGA & AAA \\
10 & CAC & AAA & 21 & GTC & AAC & 32 & GGA & AAC \\
11 & CAC & ACC & 22 & GTC & ACC & 33 & GGA & ACC \\
\hline
\end{tabular}

In the band analysis, we considered especially those located between 200 and 700 bp. The bands located in the associated group in each species were taken as the model for the species molecular characterization. For each combination of primers, the amount of polymorphic bands and the percentage of each combination was established in the five bulk. In each of the combinations tested was taken as polymorphism any band that was different compared to the species group.

\section{RESULTS AND DISCUSSION}

Based on the DNA mixture of individuals of each specie was generated an AFLP profile of the five bulks by 33 primer combinations, resulting in 803 polymorphic fragments with $91.65 \%$ of polymorphism, the minimum and maximum number of fragments per primer was 9 and 62, respectively. Figure 1 shows the pattern of fragments formed by the DNA bulk and polymorphism found by BSA 


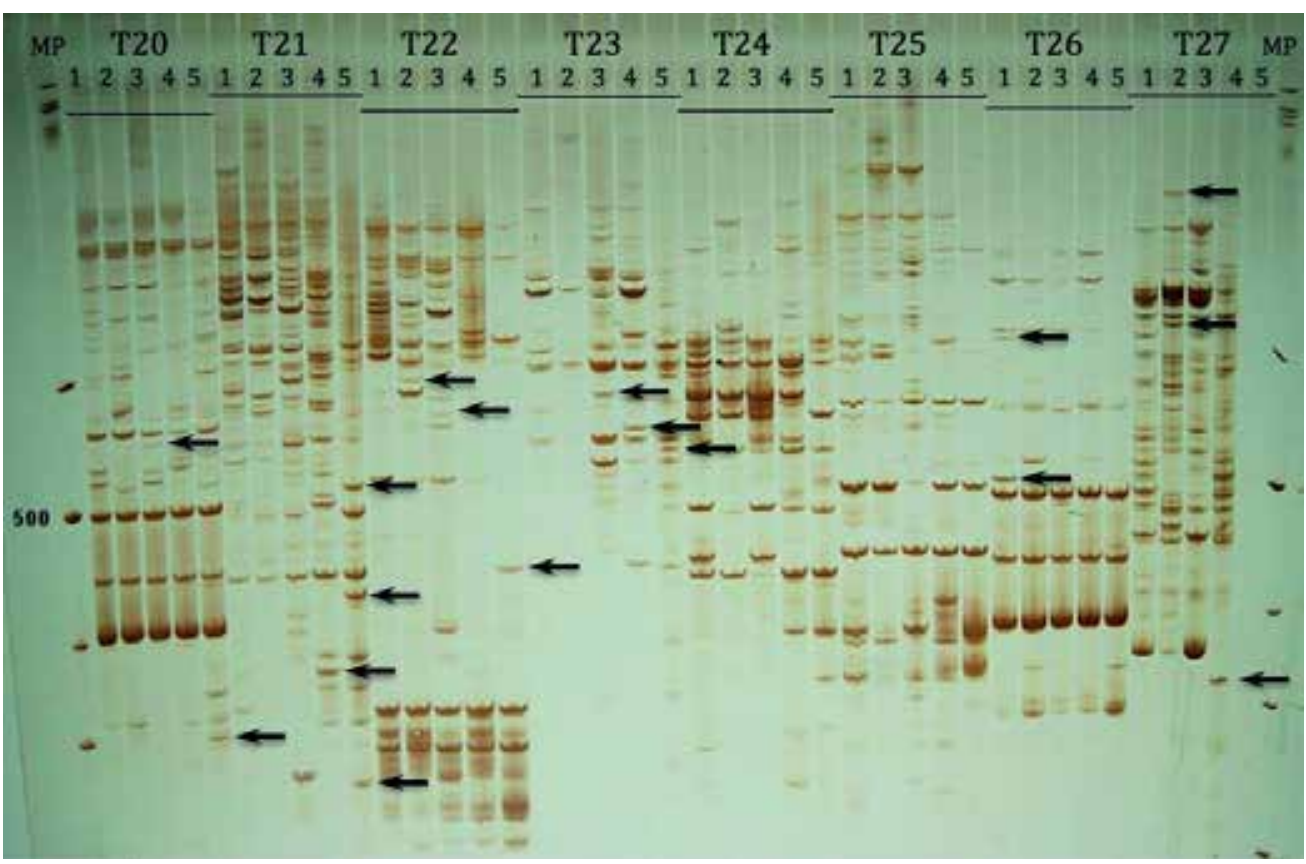

Figure 1. Banding pattern formed by bulk DNA. They are suitable candidate markers associated with specific species in eucalypts. ${ }^{*}$ Rail $1=E$. brassiana, rail $2=E$. saligna, rail $3=E$. tereticornis, rail $4=E$. urophylla, rail $5=E$. grandis. $M P=D N A$ Ladder $1 \mathrm{~Kb}$.

method. Considering each AFLP fragment as an independent locus, 868 different fragments were analyzed. The standard AFLP bands proved to be consistent and highly reproducible.

A total of 67 markers was identified to be Eucalyptus species specific, ranging between 200 and $700 \mathrm{bp}$, according to each primer set.

It was found seven candidate fragments for $E$. brassiana, 18 fragments for E. saligna, 12 for $E$. tereticornis, 13 fragments for $E$. urophylla and 17 fragments for $E$. grandis, as shown in Table 4. In figure 1 shows treatments from 21 to 27 , candidate tags were identified by Bulk-DNA to identify the species under study.

Of the 33 primers tested, the best combinations for species identification was T30 treatment, composed of $\mathrm{M}+\mathrm{GGT} / \mathrm{E}+\mathrm{ACC}$ primer, which detected $70 \%$ of $E$. urophylla individuals. The treatment T33 (M + GGA / E + ACC primer) identify $60 \%$ of $E$. saligna individuals; the T21 treatment $(\mathrm{M}+\mathrm{GTC} / \mathrm{E}+\mathrm{AAC}$ primer), had two markers, one $60 \%$ and the other $50 \%$ in the identification of $E$. grandis individuals. In T26 treatment $(\mathrm{M}+\mathrm{GGC} / \mathrm{E}+\mathrm{AAA}$ primer), there was only confirmed $30 \%$ of E. brassiana individuals, and also for T28 treatment (M + GGC / E + ACC primer), was detected $30 \%$ of $E$. tereticornis individuals, as shown in figure 2. The combinations presented in this study show a high degree of polymorphism identifying candidate fragments for the species identification, with an average of $95.65 \%$. However, once the bulk was opened, DNA detection power has decreased, from 30 to $70 \%$ of fragment frequency. Our choice of restriction enzymes and primer sequences was based on studies performed in Eucalyptus by Leite et al, 2011, which detected the different primers exhibiting a maximum number of bands on acrylamide gels (results not showed). Leite et al. (2011) considers these primer combinations highly informative, being common and polymorphic in the eucalyptus genome, which makes these sequences valuable for the design of the other primer to generate polymorphisms, both for linkage maps or phy- 
TEMAS AGRARIOS - Vol. 22:(2) Julio - Diciembre 2017 (33 - 42)

Table 4. Primer combinations used for obtaining bands associated with the identification of Eucalyptus species.

\begin{tabular}{|c|c|c|c|c|c|c|c|c|}
\hline \multirow{2}{*}{ Treatment } & \multicolumn{2}{|c|}{ Primer combinatons } & \multicolumn{5}{|c|}{ DNA Bulk } & \multirow{2}{*}{$\begin{array}{l}\text { Candidate } \\
\text { fragments }\end{array}$} \\
\hline & $\begin{array}{c}\text { MSel } \\
\text { primer }\end{array}$ & $\begin{array}{l}\text { EcoRI } \\
\text { primer }\end{array}$ & $\begin{array}{c}\text { sp 1/E. } \\
\text { brassiana }\end{array}$ & $\begin{array}{c}\text { sp2/E. } \\
\text { brassiana }\end{array}$ & $\begin{array}{c}\text { sp1/E. } \\
\text { brassiana }\end{array}$ & $\begin{array}{c}\text { sp2/E. } \\
\text { brassiana }\end{array}$ & $\begin{array}{c}\text { sp2/E. } \\
\text { brassiana }\end{array}$ & \\
\hline 1 & GTG & AGA & 0 & 1 & 1 & 0 & 0 & 2 \\
\hline 2 & GTG & $\mathrm{AGC}$ & 0 & 2 & 0 & 0 & 0 & 2 \\
\hline 3 & GTG & AGG & 0 & 0 & 0 & 0 & 1 & 1 \\
\hline 4 & GTG & $\mathrm{ACA}$ & 0 & 2 & 3 & 0 & 0 & 5 \\
\hline 5 & GTT & AGC & 0 & 2 & 0 & 0 & 0 & 2 \\
\hline 6 & CAG & $\mathrm{AAC}$ & 0 & 1 & 0 & 0 & 5 & 6 \\
\hline 7 & CAG & AAA & 0 & 0 & 0 & 2 & 0 & 2 \\
\hline 8 & CAG & $\mathrm{ACC}$ & 0 & 0 & 1 & 1 & 1 & 3 \\
\hline 9 & CAC & $\mathrm{AAC}$ & 0 & 0 & 0 & 0 & 1 & 1 \\
\hline 10 & CAC & AAA & 0 & 0 & 0 & 0 & 0 & 0 \\
\hline 11 & CAC & $\mathrm{ACC}$ & 0 & 0 & 0 & 0 & 0 & 0 \\
\hline 12 & CAA & $\mathrm{AAC}$ & 0 & 0 & 0 & 0 & 1 & 1 \\
\hline 13 & CAA & AAA & 0 & 0 & 1 & 0 & 0 & 1 \\
\hline 14 & CAT & AAA & 0 & 0 & 0 & 1 & 0 & 1 \\
\hline 15 & CAT & AAC & 0 & 1 & 0 & 0 & 0 & 1 \\
\hline 16 & CAT & $\mathrm{ACC}$ & 0 & 0 & 0 & 0 & 0 & 0 \\
\hline 17 & ССТ & AAA & 0 & 1 & 1 & 0 & 1 & 3 \\
\hline 18 & СCТ & AAC & 0 & 0 & 0 & 0 & 2 & 2 \\
\hline 19 & ССТ & $\mathrm{ACC}$ & 0 & 0 & 0 & 0 & 0 & 0 \\
\hline 20 & GTC & AAA & 0 & 0 & 1 & 0 & 1 & 2 \\
\hline 21 & GTC & AAC & 0 & 0 & 0 & 1 & 3 & 4 \\
\hline 22 & GTC & $\mathrm{ACC}$ & 0 & 1 & 1 & 1 & 0 & 3 \\
\hline 23 & GAA & AAA & 0 & 0 & 1 & 1 & 1 & 3 \\
\hline 24 & GAA & AAC & 0 & 0 & 0 & 0 & 0 & 0 \\
\hline 25 & GAA & $\mathrm{ACC}$ & 0 & 0 & 0 & 0 & 0 & 0 \\
\hline 26 & GGC & AAA & 2 & 0 & 0 & 0 & 0 & 2 \\
\hline 27 & GGC & AAC & 0 & 2 & 0 & 1 & 0 & 3 \\
\hline 28 & GGC & $\mathrm{ACC}$ & 2 & 0 & 0 & 4 & 0 & 6 \\
\hline 29 & GGT & AAA & 0 & 0 & 1 & 0 & 0 & 1 \\
\hline 30 & GGT & $\mathrm{ACC}$ & 1 & 0 & 0 & 1 & 0 & 2 \\
\hline 31 & GGA & AAA & 0 & 1 & 0 & 0 & 0 & 1 \\
\hline 32 & GGA & AAC & 1 & 2 & 0 & 0 & 0 & 3 \\
\hline 33 & GGA & $\mathrm{ACC}$ & 1 & 2 & 1 & 0 & 0 & 4 \\
\hline Total & & & 7 & 18 & 12 & 13 & 17 & 67 \\
\hline
\end{tabular}

E. brassiana

E. saligna

E. tereticornis

E. urophylla

E. grandis

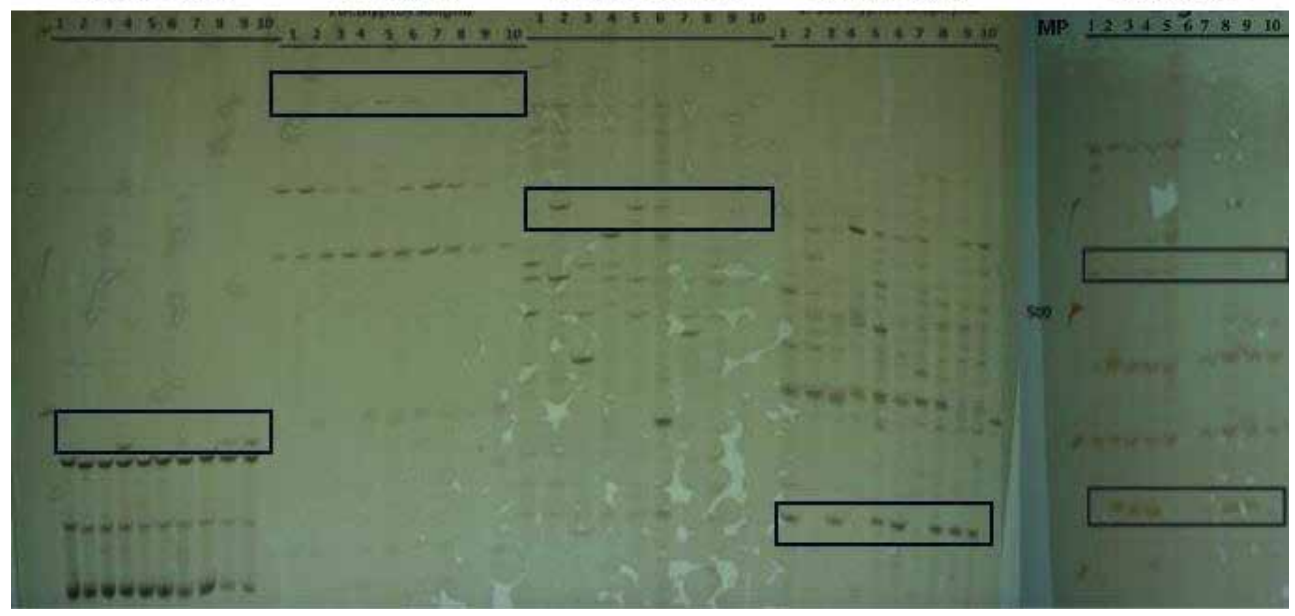

Figure 2. Standard bands formed by DNA bulk open. For confirmation marks associated with specific species in Eucalyptus. ${ }^{*} \mathrm{sp} 1=E$. brassiana, $\mathrm{sp} 2=E$. saligna, $\mathrm{sp} 3=E$. tereticornis, $\mathrm{sp} 4=E$. urophylla, $\mathrm{sp} 5=E$. grandis. $\mathrm{MP}=\mathrm{DNA}$ Ladder $1 \mathrm{~Kb}$. 
sical maps. This AFLP technique has been used to identify markers linked to plagues resistance genes (Najimi et al. 2002) and assess genetic diversity in several important forest plantations including Eucalyptus (Steane et al. 2011).

BSA efficiency has been witnessed in other studies on the identification of markers linked to the genes that control resistance to rust on Eucalyptus sp. identifying polymorphism genetically linked to the characteristic resistance groups (Zamprogno et al. 2008). According to Domingues et al. (2006), BSA technique allowed the identification of molecular markers linked to early flowering in $E$. grandis by RAPD (Random amplified polymorphic DNA) and SCAR (Sequence Characterized Amplified Region) with $60 \%$ of efficiency, confirming the usefulness of this technique as a molecular tool. These studies show that for an effective exploitation of bulked segregant analysis method, the only requirement is the existence of a segregating population of a gene of interest (Michelmore et al. 1991). Mellish et al. (2002), exploring the genetic diversity of the forage populations from the genus Agropyron spp. opted to use bulk and AFLP markers in identifying intra-population variation.

Likewise, Herrmann et al. (2005) worked with bulk by AFLP analysis to determine the genetic diversity and relationships within and among red clover populations (Trifolium pratense L.).

The bulk analysis in white clover plants (Trifolium repens L.) by AFLP markers proved to be a powerful tool for the fast screening of genetic variability to identify cultivars (Kolliker et al. 2001).

According to Michelmore et al. (1991), BSA technique is a method that allows the identification of markers in specific genomic regions linked to any specific gene or genomic region. Zhu et al. (1998) raised some questions about the effectiveness of DNA bulks in relation to the low sensitivity to detect polymorphism using AFLP markers.

Fuchs et al. (2011), successfully identified genes associated with abnormal seedlings of Eucalyptus who died in a few months by BSA technique.

However, when analyzed the bulks in studies with onion, barley, potato, lettuce, cabbage, and linen, the frequency of fragments was reduced below $50 \%$, concluding that by using this method was not found a practical approach to detect genetic polymorphisms (Van Treuren 2001). Guthridge et al. (2001), showed that profiles generated from individual samples could be or not present in the bulk samples, showing a high relationship between the frequency of occurrence and the presence of fragments in bulk samples.

\section{CONCLUSIONS}

In this investigation, we show that the AFLP technique combined with BSA can play an important role in identification of specific species Eucalyptus as it allowed to select a series of polymorphic markers associated with different Eucalyptus species, confirming 70\% of E. urophylla and $60 \%$ of $E$. saligna and $E$. grandis individuals. These molecular markers can be used as auxiliary tool to the rapidly and efficiently identification of some brands associated with the identification of species of Eucalyptus, in a faster and economical way, thus aiding breeding programs that do not have access to more expensive technologies.

\section{REFERENCES}

Ballesta, P., Mora, F., Contreras-Soto, R. I., Ruiz, E. and Perret, S. 2015. Analysis of the genetic diversity of Eucalyptus cladocalyx (sugar gum) using ISSR markers. Acta Scientiarum. Agronomy, 37(2): 133. https://doi.org/10.4025/actasciagron. v37i2.19307. 
Barbour, R., Potts, B and Vaillancourt, R. 2005. Pollen dispersal from exotic Eucalyptus plantations. Cons. Genet. 6: 253-257. https://doi.org/10.1007/s10592-004-7849-z

Blanco, M. and Valverde, R. 2005. Analisis de segregantes agrupados (BSA) para la deteccion de AFLPS ligados al GEN de resistencia a PVX Solanum commersonii. Agronomia Costarricense, 29(2): 45-55.

Brondani, R., Brondani, C., Tarchini, R. and Grattapaglia, D. 1998. Development, characterization and mapping of microsatellite markers in Eucalyptus grandis and E. urophylla. Theo App Gen, 97: 816-827. https://doi.org/10.1007/ s001220050961.

Creste, S., Tulmann Neto, A. and Figueira, A. 2001. Detection of single sequence repeat polymorphisms in denaturing polyacrylamide sequencing gels by silver staining. Plant Molecular Biology Reporter, 19: 299-306. https://doi. org/10.1007/BF02772828.

Denison, N. and Kietzka, J. 1993. The use and importance of hybrid intensive forestry in South Africa. South Afri Fore J 165: 5560. https://doi.org/10.1080/00382167.19 93.9629390.

Domingues, D. S., Cazerta, A., Costrato, V., José, D. Oda, S., Marino, C. L. and Marino, L. 2006. Identificação de marcador RAPD e SCAR relacionados ao caractere florescimento precoce em Eucalyptus grandis. Ciência Florestal, 16(3): 251-260. Retrieved from http:// doi.org/10.5902/198050981906.

Doyle, J. and Doyle, J. 1990. Isolation of plant DNA from fresh tissue. Focus, 12: 13-15.

Forrester, D. I. and Smith, R. 2012. Faster growth of Eucalyptus grandis and Eucalyptus pilularis in mixed-species stands than monocultures. Forest Ecology and Management, 286: 81-86. https:// doi.org/10.1016/j.foreco.2012.08.037.
Fuchs, M., Lourenção, J., Tambarussi, E., Bortoloto, T., Oda, S., Nogueira, F. and Marino, C. 2011. Genome characterization of a Eucalyptus natural mutant. BMC Proceedings, 5(7): 65. https://doi.org/10.1186/1753-6561-5S7-P65.

Gonçalves, J., Alvares, C., Higa, A., Silva, L., Alfenas, A., Stahl, J. and Epron, D. 2013. Integrating genetic and silvicultural strategies to minimize abiotic and biotic constraints in Brazilian eucalypt plantations. Forest Ecology and Management, 301: 6-27. https://doi. org/10.1016/j.foreco.2012.12.030.

Grattapaglia, D. and Kirst, M. 2008. Eucalyptus applied genomics: from gene sequences to breeding tools. The New Phytologist, 179(4): 911-29. https://doi.org/10.1111/ j.1469-8137.2008.02503.x.

Grattapaglia, D., Ribeiro, V. and Rezende, G. 2004. Retrospective selection of elite parent trees using paternity testing with microsatellite markers: an alternative short term breeding tactic for Eucalyptus. TAG Theoretical and Applied Genetics, 109(1): 192-199. https://doi.org/10.1007/ s00122-004-1617-9.

Guthridge, K., Dupal, M., Kölliker, R., Jones, E., Smith, K. and Forster, J. 2001. AFLP analysis of genetic diversity within and between populations of perennial ryegrass (Lolium perenne L.). Euphytica, 122: 191-201. https://doi. org/10.1023/A:1012658315290.

Harwood, C. 2011. New introductions - doing it right. In Developing a eucalypt resource. Learning from Australia and elsewhere. Ed. J. Walker. Wood Technology Research Centre, University of Canterbury, Christchurch, New Zealand: 125-136. 
Herrmann, D., Boller, B., Widmer, F. and Kölliker, R. 2005. Optimization of bulked AFLP analysis and its application for exploring diversity of natural and cultivated populations of red clover. Genome / National Research Council Canada $=$ Génome $/$ Conseil National de Recherches Canada, 48(3): 474-86. https://doi.org/10.1139/g05-011.

IBA. Indústria Brasileira de árvores- iba. 2015. Available online: http://www.iba.org/ shared/iba_2014_pt.pdf. (accessed on 23 april 2017).

Ishii, K. 2009. DNA Markers in Eucalyptus with emphasis on species identification. Environment Control in Biology, Tokyo, 47 (1): 1-11.

Jones, R., McKinnon, G., Potts, B. and Vaillancourt, R. 2005. Genetic diversity and mating system of an endangered tree Eucalyptus morrisbyi. Austra J Bot 53: 367-377. https://doi.org/10.1071/ BT04182.

Jones, M., Shepherd, M., Henry, R. and Deves, A. 2008. Pollen flow in Eucalyptus grandis determined by paternity analysis using microsatellite markers. Tree Genet. Geno. 4: 37-47. https://doi.org/10.1007/ s11295-007-0086-0.

Kolliker, R., Jones, E. Jahufer, M. and Forster, J. 2001. Bulked AFLP analysis for the assessment of genetic diversity in white clover (Trifolium repens L.). Euphytica, 121(3): 305-315. Retrieved from $<$ Go to ISI >://000171802500012

Leite, V., Santos O., Sagawa, C., Gonzalez, E., Fagundes, M., Oda, S. and Marino, C. 2011. Identification of genomic regions related to early flowering in Eucalyptus. BMC Proceedings, 5(7):53. http://doi. org/10.1186/1753-6561-5-S7-P53
Mellish, A., Coulman, B. and Ferdinandez, Y. 2002. Genetic Relationships among Selected Crested Wheatgrass Cultivars and Species Determined on the Basis of AFLP Markers. Crop Science, 42(5): 1662-1668. http://doi.org/10.2135/ cropsci2002.1662

Michelmore, R., Paran, I. and Kesseli, R. 1991. Identification of markers linked to disease-resistance genes by bulked segregant analysis: a rapid method to detect markers in specific genomic regions by using segregating populations. Proceedings of the National Academy of Sciences of the United States of America, 88(21): 9828-32. http://doi.org/10.1073/pnas.88.21.9828

Mora, F., Arriagada, O., Ballesta, P. and Ruiz, E. 2016. Genetic diversity and population structure of a drought-tolerant species of Eucalyptus, using microsatellite markers. J. Plant Biochem. Biotechnol.1-8 . https:// doi.org/10.1007/s13562-016-0389-z

Najimi, B., Boukhatem, N., Jaafri, S., Jlibène, M., Paul, R. and Jacquemin, J. 2002. Amplified fragment length polymorphism (AFLP) analysis of markers associated with $\mathrm{H} 5$ and $\mathrm{H} 22$ Hessian fly resistance genes in bread wheat. Biotechnol Agron Soc Environ 6: 79-85.

Payn, K., Dvorak, W., Janse, B. and J, Myburg, A. 2008. Microsatellite diversity and genetic structure of the commercially important tropical tree species Eucalyptus urophylla, endemic to seven islands in eastern Indonesia. Tree Genet Gen 4: 519-530. https:// doi.org/10.1007/s11295-007-0128-7

Poltri, S., Zelener, N., Traverso, J., Gelid, P., and Hopp, H. 2003. Selection of a seed orchard of Eucalyptus dunnii based on genetic diversity criteria calculated using molecular markers. Tree Physiology, 23(9): 625-32. Retrieved from http://www.ncbi. nlm.nih.gov/pubmed/12750055. https:// doi.org/10.1093/treephys/23.9.625 
Pongitory, V., Moura, G., Blume, E., Flores, E. and Jaya, D. 2004. O Germoplasma De Eucalyptus urophylla S. T. Blake No Brasil Vicente. Comunicado Técnico, Blake 1977).

Potts, B. and Dungey, H. 2004. Interspecific hybridization of Eucalyptus: key issues for breeders and geneticists. New Forests, 27: 115-138. https://doi. org/10.1023/A:1025021324564.

Randall, B., Walton, D., Lee, D. and Wallace, H. 2016. The risk of pollen-mediated gene flow into a vulnerable eucalypt species. Forest Ecology and Management 381: 297-304. https://doi.org/10.1016/j. foreco.2016.09.042.

Rivera-Jiménez, H., Alvarez Soto, A., Palacio Mejia, J., Barrios Leal, D. and Lopez Alvarez, D. 2011. Diversidad genética intra e inter-específica de ñame (Dioscorea spp.) de la región Caribe de Colombia mediante marcadores AFLP. Acta Agronómica, 60(4), 328-338. Retrieved from http://www.revistas.unal.edu.co/index.php/acta_agronomica/article/view/28847/40344

Santos, E. 2011. Program de melhoramento genético de eucalipto da Embrapa Florestas: resultados e perpectivas. Embrapa Florestas, Brasil. 214.

Silva, P., Sebbenn, A. and Grattapaglia, D. 2014. Pollen-mediated gene flow across fragmented clonal stands of hybrid eucalypts in an exotic environment. Forest Ecology and Management, 356: 293-298. https:// doi.org/10.1016/j.foreco.2014.12.005

Silva, P., Sebbenn, A. and Grattapaglia, D. and Sebbenn A. 2015. Use of genetic markers to build a new generation of Eucalyptus pilularis breeding population. Silvae Genet, 64: 170-181. https://doi. org/10.1515/sg-2015-0016

Silva, P., Campoe, O., Paula, R. and Lee, D. 2016. Seedling Growth and Physiological Responses of Sixteen Eucalypt Taxa under Controlled Water Regime Forests 7 (6): 110.
Silva, P., Sebbenn, A., Grattapaglia, D. and Conti J. 2017. Realized pollen flow and wildling establishment from a genetically modified eucalypt field trial in Southeastern Brazil Forest Ecology and Management, 385: 161-166.

Soares, N., Silva, M., Rezende, J. and Gomes, $M$. 2010. Competitividade da cadeia produtiva da madeira de eucalipto no Brasil. Revista Árvore, 34(5): 917-928. http://doi. org/10.1590/S0100-67622010000500017.

Steane, D., Nicolle, D., Sansaloni, C., Petroli, C., Carling, J., Kilian, A. and Vaillancourt, R. 2011. Population genetic analysis and phylogeny reconstruction in Eucalyptus (Myrtaceae) using highthroughput, genome-wide genotyping. Molecular Phylogenetics and Evolution, 59(1): 206-24. http://doi.org/10.1016/j. ympev.2011.02.003.

Van Treuren, R. 2001. Efficiency of reduced primer selectivity and bulked DNA analysis for the rapid detection of AFLP. pdf. Euphytica, 117(1): 27-37. https://doi. org/10.1023/A:1004003121622

Vos, P., Hogers, R., Reijans, M., Van, T., Hornes, M., Frijters, A., Pot, J., Peleman, J., Kuiper, M. and Zabeau, M. 1995. A new technique for DNA fingerprinting. Nucleic Acids Research, 44(21), 388-396. https:// doi.org/10.1093/nar/23.21.4407

Zamprogno, K., Furtado, E., Marino, C., Bonine, C. and Dias, D. 2008. Utilização de análise de segregantes agrupados na identificação de marcadores ligados a genes que controlam a resistência à ferrugem (Puccinia psidii Winter) em Eucalyptus sp. Summa Phytopathologica, 34(3), 253-255. https://doi.org/10.1590/ S0100-54052008000300009

Zhu, J., Gale, M., Quarrie, S., Jackson, M. and Bryan, G. 1998. AFLP markers for the study of rice biodiversity. TAG Theoretical and Applied Genetics, 96(5), 602-611. https://doi.org/10.1007/s001220050778. 